
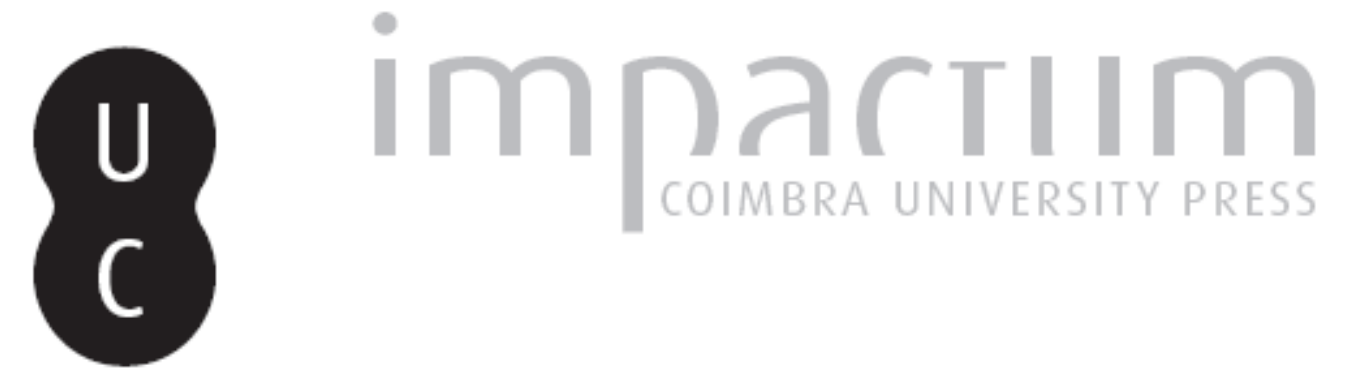

\title{
Toward a formal ontology for narrative
}

\section{Autor(es): $\quad$ Ciotti, Fabio}

Publicado por: Centro de Literatura Portuguesa; Imprensa da Universidade de Coimbra

URL persistente:

URI:http://hdl.handle.net/10316.2/38725

DOI:

DOI:http://dx.doi.org/10.14195/2182-8830_4-1_2

Accessed : $\quad$ 26-Apr-2023 11:31:15

A navegação consulta e descarregamento dos títulos inseridos nas Bibliotecas Digitais UC Digitalis, UC Pombalina e UC Impactum, pressupõem a aceitação plena e sem reservas dos Termos e Condições de Uso destas Bibliotecas Digitais, disponíveis em https://digitalis.uc.pt/pt-pt/termos.

Conforme exposto nos referidos Termos e Condições de Uso, o descarregamento de títulos de acesso restrito requer uma licença válida de autorização devendo o utilizador aceder ao(s) documento(s) a partir de um endereço de IP da instituição detentora da supramencionada licença.

Ao utilizador é apenas permitido o descarregamento para uso pessoal, pelo que o emprego do(s) título(s) descarregado(s) para outro fim, designadamente comercial, carece de autorização do respetivo autor ou editor da obra.

Na medida em que todas as obras da UC Digitalis se encontram protegidas pelo Código do Direito de Autor e Direitos Conexos e demais legislação aplicável, toda a cópia, parcial ou total, deste documento, nos casos em que é legalmente admitida, deverá conter ou fazer-se acompanhar por este aviso.

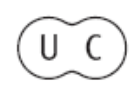




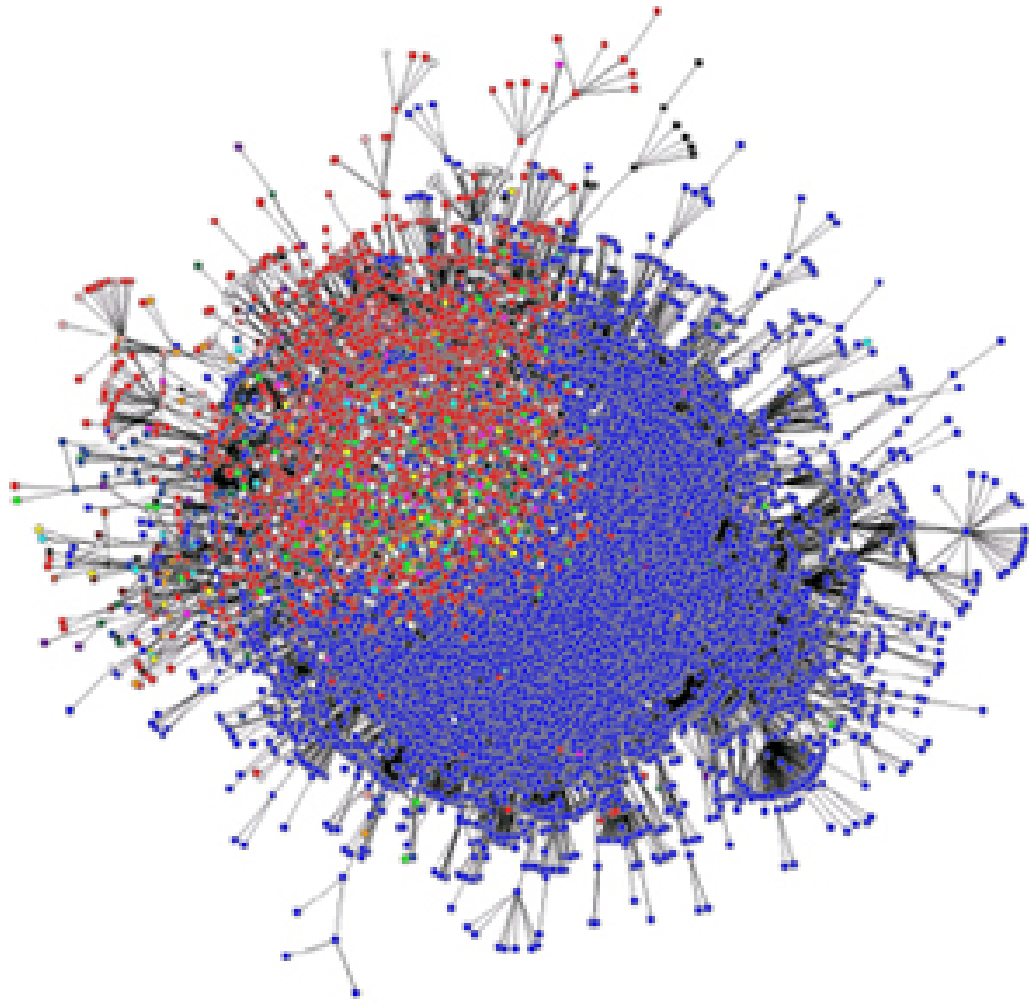

Vol. 4.1 (2016) ISSN 2182-8830

'Estudos Literários Digitais 1'

Manuel Portela e António Rito Silva (orgs.) 


\title{
Toward a Formal Ontology for Narrative FABIO CIOTTI
}

\author{
Università di Roma Tor Vergata
}

\begin{abstract}
In this paper the rationale and the first draft of a formal ontology for modeling narrative texts are presented. Building on the semiotic and structuralist narratology, and on the work carried out in the late 1980s by Giuseppe Gigliozzi in Italy, the focus of my research are the concepts of character and of narrative world/space. This formal model is expressed in the OWL 2 ontology language. The main reason to adopt a formal modeling approach is that I consider the purely probabilistic-quantitative methods (now widespread in digital literary studies) inadequate. An ontology, on one hand provides a tool for the analysis of strictly literary texts. On the other hand (though beyond the scope of the present work), its formalization can also represent a significant contribution towards grounding the application of storytelling methods outside of scholarly contexts. Keywords: computational narratology; digital literary studies; formal ontology; character theory; distant reading; text analysis.
\end{abstract}

\section{Resumo}

Este artigo contém a justificação e um primeiro esboço de uma ontologia formal para a modelação de textos narrativos. Tomando como ponto de partida a narratologia semiótica e estruturalista, assim como o trabalho levado a cabo por Giuseppe Gigliozzi em Itália, no final da década de 1980, a minha investigação centra-se nos conceitos de personagem e de espaço/mundo narrativo. Este modelo formal é expresso através da linguagem de ontologia OWL 2. É adotada uma abordagem de modelação formal porque considero que os métodos puramente quantitativos-probabilísticos (atualmente em voga nos estudos literários digitais) são inadequados. Uma ontologia proporciona, por um lado, uma ferramenta de análise de textos estritamente literários. Por outro lado (embora isso exceda o âmbito do presente artigo), a sua formalização pode representar também um contributo significativo para fundamentar a aplicação de métodos narrativos fora de contextos académicos. Palavras-chave: narratologia computacional; estudos literários digitais; ontologia formal; teoria da personagem; leitura distante; análise textual.

\section{Introduction}

$\mathbf{I}$ $\mathrm{n}$ this paper I present the theoretical rationale of a research project at the intersection of narratology and computer science. The main project objective is to analyze some essential concepts of narratology, building on the work carried out since the late 1980s by Giuseppe Gigliozzi in Italy, and to model them using a formal ontology. In particular, the research focuses on the concepts of character and narrative world/space. This con- 
ceptual analysis and the consequent formal modeling is specified according to the standard OWL 2 ontology language (W3C, 2012a).

The main reason to adopt a formal modeling approach is that I consider the purely probabilistic-quantitative methods now widespread in digital literary studies largely inadequate. In my opinion they fail to catch the intrinsic intensional and semantic nature of many literary phenomena. On the contrary, this nature can be attained and made explicit and computable using a mixed human-machine approach, like that required by ontology modeling.

The formal ontology, on one side, provides a tool for the analysis of literary texts stricto sensu. In fact, it can be used to define a formal framework to guide the digital annotation of literary works by individual scholars working on a single text, or by a community working on large corpora. The aggregate of structured data can then be queried and analyzed using automatic logical reasoners. On the other side (which is not addressed in the present work), the formalization can also represent a significant contribution in grounding the application of storytelling methods outside of scholarly contexts.

\section{Computational narratology}

The modeling of narrative artifacts with computational methods has a long history, rooted in the classical Artificial Intelligence studies of the 1970s aimed at building a computational model for natural language processing and knowledge representation (Minsky, 1974; Shank and Abelson 1977; Lehnert, 1981; Van Dijk, 1977 and 1979). Later, a formal field of study, named "computational narratology", was established and became one of the subdivisions of the post-classical narratology (Herman, 1999).

The purpose of computational narratology is the study of narrative from the point of view of computation and information processing; it focuses on the algorithmic processes involved in creating and interpreting narratives and in modeling narrative structure in terms of formal, computable representations (Mani, 2013). The field of story grammars, which stems from the tradition of formalist and structuralist narratology mixing it with concepts from knowledge representation and action theory, and the notions of "narrative action", "time" and "event" (Meister, 2003), have traditionally been the central theme of studies in this field. It should be noted, however, that the main concern of computational narratology has seldom if ever been the analysis of actual literary narrative texts. Its models have always been confined to a very high level of abstraction, or have been applied to the generation or comprehension of ad hoc simple examples of narrative "snippets".

Recently, under the pressure of the Semantic Web effort, attention has turned toward the use of ontological technologies (Gruber, 1993) for the representation of narrative structures both for the purposes of literary and narratological research (Zöllner-Weber, 2006 and 2007; Zöllner-Weber and 
Witt, 2006) and, mainly, for the possible applications of automatic storytelling processes in training, communication and media industry contexts (Damiano and Lieto, 2013; Jewell, 2005).

\section{Looking back: searching for a rationale of digital literary studies}

In the continuously growing Digital Humanities community, the attraction for novelty often leads to the enthusiastic adoption of new methods and tools, without an adequate epistemological and methodological consideration.

I believe that sometimes to make a step forward in scientific research we need to look back, as Victor Šklovskij suggested, at our grandparents or uncles, and not at our "deconstructed" and postmodernist fathers and mothers or elder brothers and sisters. I believe, in short, that we should have the consciousness of the wealth of ideas and theories that our disciplines have adopted in the past to deal with critical problems similar to those we are facing today, although equipped with a profoundly different repertoire of analytical tools and methods.

This is particularly true for literary studies: the theoretical heritage of structural and semiotic text analysis could prove a mine of theories and methods, if properly re-contextualized and adapted to the formal requirements of computational environments. This was the perspective adopted between the late 1980s and early 1990s by a small group of researchers at the University of Rome, gathered around the leading figure of Tito Orlandi. In particular, it is worth mentioning the late Giuseppe Gigliozzi.

Before the fulcrum of his activities would shift to the theory and application of text encoding and markup languages, Gigliozzi for several years experimented, with the help of his students, the application of Artificial Intelligence technologies to the analysis of narrative texts. Although the strong view of AI had already faded, the methods and concepts developed in that area were still very popular. Moreover, it is obvious that they exercised a considerable attraction among a generation of scholars that had based their scholarship on the theoretical horizon that from Greimas and Bremond expands to Eco and Segre, but were also interested in "collateral" authors such as Van Dijk and the Group $\mu$ (Gigliozzi, 1986 and 1987).

This early research led to the development of two Lisp applications. The first was SEBNET (Gigliozzi et al., 1987), an expert system capable of analyzing and generating fairy tales, starting from a paradigmatic description of the stereotypical characters and situations and from a story grammar. The second, SEB, was a semantic network application to analyze the relations between the characters in more complex narratives, which was applied to study some short stories by Luigi Pirandello (Gigliozzi and Giuliani, 1993a and 
1993b). At the same time Gigliozzi developed a deep epistemological awareness about the role of information technology in literary studies: ${ }^{1}$

The computational machine - as well as the knowledge behind it - must be useful in two phases. The first is the moment of the theoretical foundation and of the initial system design and implementation, where the new methods must contribute to redefining the theory and the analysis framework. The second is when the application of a functioning computational tool makes it possible to scrutinize large quantities of data with a high level of precision, and to exploit those results for a new and deeper theoretical reflection (Gigliozzi et al., 1987: 152)

I cannot give more details here about this theoretical and experimental work. What I have said is enough, I believe, to give a preliminary justification for my position: I am convinced that to make a step forward, at least in the domain of text analysis (literary or not), and in particular of narrative fiction, it is appropriate to look back and reconsider the semiotic and structuralist theories of the 1970s and 1980s. The experiments at the University of Rome I have mentioned were pioneering in this respect. The evolution of semantic technologies of the past few years gives us an apparatus of computational methods and tools that can help to operationalize - to follow the suggestion of Moretti (2013) - part of that theoretical and analytical tradition, and to adapt it to the context of the digital turn in literary studies we are now witnessing.

The objection to this proposal is quite obvious: now that the purely quantitative techniques of big data analytics and distant reading appear to open unlimited horizons for literary studies without asking us to make the effort to formalize elusive concepts and processes, and to give shape and structure to our digital objects, why engage in a strenuous theoretical analysis and in a much more difficult (and, all things considered, a high-risk-offailure) formalization of our texts? Why venture into the risky world of ontologies and semantic languages when you can download thousands of texts from the Hathi Trust (https:/ /www.hathitrust.org) repository and run a topic modeling (Underwood, 2012; Jockers, 2013) software on them, to unveil what was hidden and you could not see?

1 This and the following Italian quotes are translated by the author. Here is the original text: "La macchina - ma anche le discipline che stanno dietro l'elaboratore devono essere utili in due fasi. In un primo momento, quello dell'implementazione del sistema e della riflessione teorica, il nuovo ambiente di ricerca e i più freschi apporti devono garantire un passo ulteriore alla teoria e all'analisi. Per la seconda fase la possibilità di gestire grandi quantità di materiali con un sistema ormai in grado di funzionare consentirà di sondare con estrema precisione l'oggetto della ricerca e di tornare con risultati non altrimenti ottenibili a un'ulteriore fase di riflessione teorica." 
My answer is multi-layered. In the first place, a distant reading approach (at least the ingenuous one, quite different from the sophisticated and dialectic position of Moretti [2013]) shows a lot of shortcomings and critical issues, which I have already identified elsewhere (Ciotti, 2014). I summarize briefly the most relevant:

1) Data mining algorithms in general are independent from the context (they can be applied as indifferently to stock exchange transactions as to very large textual corpora). They identify similarities and recurring patterns independently from the semantics of data. Humanities and literary data are semantically contextualized.

2) Text mining is agnostic about the granularity of the data to which it is applied. Texts are only sequences of n-grams, and the probabilistic rules adopted to calculate the relevance of a given set of $\mathrm{n}$-grams are completely independent from the fact that the units of analysis are individually-coded characters, or linguistic tokens of greater extension.

3) If a very large textual set is composed of documents spread over a long period of time, diachronic variation of the form and usage of the language (both on the syntactic and semantic level) can invalidate purelyquantitative and statistic measures.

4) Data in literary studies do not precede formal modeling; on the contrary, they are the product of modeling. It is very dubious to assume innocently a data set as the starting point of a meaningful analysis.

5) Meaning in literary texts is multi-layered, and some layers do not have direct lexicalization or they have a very complex and dispersed one (think about aspects of a narrative text at a different abstraction level like anaphora, themes, plot and fabula). Purely quantitative analyses apply only to textual degré zéro, on which the secondary modeling systems of literature builds their significance.

6) Texts (especially literary texts) are essentially intentional objects (Dennett, 1990): the meaning of a word, the usage of a metaphor, the choice of a metric or rhythmic solution in a poetic text are determined by the attribution of sense and meaning by the author and by the reader. Intentional phenomena do not follow regular patterns and are hardly (if ever) detectable by statistical methods.

This last point is in fact the real core of my argumentation, since it epitomizes a fact that most readers, and among them most literary scholars, firmly believe: the interpretation of texts is an intentional process, and is intrinsically based on the production and application of a set of intentional notions and terms (e.g. character, influence, point of view, authorship, and agency) to explain what the text means and how it means. Semiotic and structural criticism has adopted towards these concepts the same stance as cognitive functionalism towards common mental notions: it has tried to explain or to translate them into formal concepts, like fabula and plot, actant, narrative 
function, isotopy, or focalization. These technical terms, though, preserve the intentional nature of text and interpretation.

This is why I believe that the convergence between semiotic and structuralist theories of literary text and current ontology and semantic driven methods represents a big chance for the future development of Digital Literary Studies. I do not mean to underestimate the utility and efficacy of massive quantitative methods in general. Under certain circumstances they are invaluable tools for tracing the shape of broader or long-term phenomena. My critical observation refers to the attempts to apply those methods to the analysis of small textual sets or even individual works. A task, which we, as literary critics, should not give up.

\section{The role of formal ontology in Digital Humanities}

In this overall picture, I want to stress the centrality of formal ontologies and ontology-building as a theoretical and methodological instrument for literary sciences. The term "ontology" has been imported from classic and medieval metaphysics to the knowledge representation domain of Artificial Intelligence since the 1980s, but its spreading is due to the ambitious vision of the Semantic Web set forth by Tim Berners-Lee in the late 1990s (Berners-Lee, Hendler and Lassila, 2001). He proposed that the information resources on the Web should be associated with a set of semantic metadata, so that their intended semantics could be accessed and processed by software agents.

The Semantic Web initiative has developed a full framework of languages and data models. The most basic one is Resource Description Framework (RDF), a data model that allows for the expression of simple "subject - predicate - object" statements, without making any commitment to the semantic of those statements. That role is reserved to the formal ontology level (Antoniou and Van Harmelen, 2008), where it is possible to give a formalized conceptual description of the field of discourse:

In the context of computer and information sciences, an ontology defines a set of representational primitives with which to model a domain of knowledge or discourse. The representational primitives are typically classes (or sets), attributes (or properties), and relationships (or relations among class members). The definitions of the representational primitives include information about their meaning and constraints on their logically consistent application (Gruber, 2009)

The general vision of the Semantic Web has failed for many technical and social reasons. Nonetheless, semantically-oriented methods and technologies have had successful applications in many restricted and controlled domains and are the basis of the Linked Data architecture that makes it pos- 
sible to share, access and interconnect rich structured data sets on the Web (Heath and Bizer, 2011).

One of the main technical benefits of formal ontologies is that they permit the application of computational inference and reasoning tools to express explanation and make predictions. Their foundation in description logic has made possible the development of efficient inference engines that can help to unveil unforeseen relationships between the concepts and objects inside the model. Moreover Semantic Web ontological formalisms, like RDF-S and OWL, provide methods to share, compose and eventually merge different ontologies, taking advantage of the relevant modeling and formalization efforts conducted in adjacent research fields.

Still more relevant in our context is the fact that they have proved to be a very powerful formal modeling tool. Given the centrality of the practice of modeling in Digital Humanities research, the application of ontologies in the context of digital textual scholarship has a deep methodological and theoretical significance. The creation of formal models based on an explicit conceptualization grants that all the critical discourses and analyses are firmly grounded in a common "setting" of the domain. This is not only a way for ensuring an already-existent knowledge exchange, but first and foremost a way to build new knowledge, since it asks us to make explicit the tacit knowledge which is a major part of literary critical work. If we want to use computing, we need to reduce the implicit and formalize, with the consciousness that formal modeling is inside the hermeneutic process and that we are expected to modify and adapt it, ad infinitum.

\section{An ontology for narrative characters}

According to the theoretical context outlined above, the theoretical foundations of this project are deeply rooted in some important concepts developed by classical and post-classical narratology. In particular, I focus on two main aspects of narrative texts which have remained at the margins of computational narratology in the past two decades (which, as I said, are geared mainly towards the computational formalization of story-grammars):

1) The notion of character and of actor/actant following the different level of abstraction proposed in the early works of Greimas (1966).

2) The notion of narrative/fictional world/space, following the idea of "narrative semiotic space" by Lotman (1972) and the theories of possible fictional worlds (Doležel, 1998; Eco, 1979; Ryan 1991).

My intention is to develop a formal ontology of these concepts, starting from the work carried out since the early 1980s by Gigliozzi and his collaborators. In that work we can find an analysis of the formal structure of the character in the novel and in the short story and some attempts to develop a computational model of the story formalized in the Lisp programming lan- 
guage. That analysis draws on a notion we can find in Umberto Eco's theory of narrative text:

Thus Little Red Riding Hood, within the framework of the story that creates her, is a mere spatiotemporal meeting of physical qualities, relations with other characters, actions performed, or passions suffered (Eco, 1979: 221)

The character, from this point of view, can be described as a representational device consisting of a set of properties. To be more precise it is a frame-like semantic structure, as defined by Marvin Misnky (1974), composed of slots whose values describe its static and dynamic features. Some of those features are the result of a hyper-codification process (Eco, 1974: 214) determined by the intertextual tradition and by the genre; other are contextual or even idiolectal, as Gigliozzi points out: ${ }^{2}$

The Character has to be seen, therefore, as a complex unity exploded in its constituent parts.

For each character we draw up a list of traits functional to the diegetization [diegesizzazione] of its role in the universe of discourse.

The List includes traits defining the qualities and traits that represent the world of actions. Both traits can be: hypercodified or variable (contextual). [...]

Given some particular traits, the series of acts that can be attributed to the character must confirm their own isotopy, that is their semantic compatibility (91: 57-58)

The following example epitomizes the structure of the features list describing a stereotypical character (the values are mere examples):

character/role: Prince

hypercodified qualitative features: handsome, rich

variable qualitative features: courageous, generous

hyper-codified action features: search, fight

derived action features: defend, save, offer, donate

object: sword

place: castle, forest

event: fight with dragon

\footnotetext{
${ }^{2}$ Orig.: "Il Personaggio è visto, quindi, come un'unità complessa che viene esplosa nei suoi costituenti. Per ogni personaggio viene stilata una Lista di marche funzionali alla diegesizzazione del ruolo che quel personaggio, nell'universo del dicibile, rappresenta. La Lista comprende marche che definiscono la qualità e marche che rappresentano il mondo delle azioni. Entrambe le marche possono essere: ipercodificate e "variabili" (o contestuali). [...]Date certe marche, la serie degli atti attribuibili all'individuo deve confermare la loro isotopia, intesa come criterio di compatibilità semica."
} 
This paradigmatic structure is projected onto the syntagmatic axis of the discourse as an isotopy. We remember that for Greimas two or more elements build an isotopy when they are semantically homogeneous, that is, when they are on the same semantic level. The character is then manifested at the discourse level as a sequence of isotopic features that represents it, describes it and determines it. Its acts will be, therefore, the actualization of the potential contained in those features.

Another contribution to the structure of our ontology of fictional character is the well-known re-factorization of the notion of narrative function (introduced by Propp 1968 and then adopted by many classical narratology scholars in the 1960s and 1970s) proposed by Greimas: ${ }^{3}$

La réinterprétation linguistique des dramatis personae que nous avons proposé à partir de la description proppienne du conte merveilleux russe a cherché à établir, en premier lieu, une distinction entre les actants relevant d'une syntaxe narrative et les acteurs reconnaissables dans les discours particulier où ils se trouvent pertinente (1983: 49)

Greimas in his theory has defined six actantial roles in his well-known model:

$\begin{array}{ccc}\text { Sender } \rightarrow & \text { Object } & \rightarrow \text { Receiver } \\ \uparrow & \\ \text { Helper } \rightarrow & \text { Subject } & \leftarrow \text { Opponent }\end{array}$

It is important to note that an actor (that is a character in the traditional sense of the word), can instantiate several actants and conversely one actantial role can be instantiated by many actors. Moreover an actantial role can be played not only by anthropomorphic characters, but also by strictly inanimate concrete objects (not able to make any action), or abstract objects.

If the actant is an abstraction of the concept of character/actor, in complex narratives one character can generate multiple personifications or roles, with different sets of semantic traits (different character frames) that in turn are actualized by different isotopies at the syntagmatic level. In general, we can say that the characters in novels are always multi-isotopic, although this aspect is quite typical of modern and postmodern literature: think of some

${ }^{3}$ English translation: "The linguistic reinterpretation of the dramatis personae that we proposed starting from the proppian description of Russian fairy tale sought to establish first of all a distinction between the actants, which belong to a narrative syntax, and the actors, recognizable in the particular speeches where they are manifested." 
epitomizing cases of complex and even multiple personalities characters like Raskol'nikov, Mattia Pascal or, taken to an extreme, Leopold Bloom.

\section{First draft of the character ontology}

At the moment the formalization is still a working draft (many details of the structure and of the names of classes and properties are to be refined), and it is limited to character ontology. The formalism adopted is the OWL $2 \mathrm{EL}$ Profile (W3C, 2012b). The rationale of this choice is both technical and methodological. First, the inference algorithms for the semantic of OWL 2 EL are tractable in polynomial time, even if this subset is satisfactorily expressive. Second, this OWL subset is based on a family of the so-called description logics (namely EL-DL; Cfr. Baader, Brandt and Lutz, 2005). In description logics the concepts and their relationships are collected in a TBox (terminological knowledge box) that represents the abstract schema or taxonomy of the modeled domain. The factual knowledge about the instances or the individuals is known as the ABox (assertions box). This neat separation reflects our need to define a general ontological model of narrative phenomena and (eventually) use it to describe actual narrative works.

In the ontology there are classes for actantial roles, for the concept of actor/character (which can be subdivided into roles) and for six types of features: object, quality, event, action, actor, place. These classes are subdivided into subclasses to distinguish between physical and mental acts, qualities, objects and so on. The assignment of a quality to an individual character is provided by five properties that relates the class of actors and the classes of the features. All the properties have zero or more cardinality (which is the default in OWL) and are asymmetric. Their domain is always the Actor class, while their ranges are the class of the respective type of feature. The image in figure 1 gives an overall view of the structure of the ontology.

I have already mentioned some of the overall advantages of the adoption of formal ontologies in digital literary studies. Considering the more restricted domain of narrative studies, our computational formalization, once finalized, can achieve various scientific objectives. In the first place, it is an attempt to draw a clear theoretical account of some key concepts of narratology and literary theory. In the second place it provides an operational version of those concepts that can be used in computational analysis of literary narrative. For instance, our OWL ontology with the addition of some rule-based clauses (W3C, 2013) can be used to explore systematically the potential relationships between the set of characters in a novel based on their properties: in a sense this would produce a (partial) account of the narrative possible “inferential walks" licensed by the text (Eco, 1979: 31). 


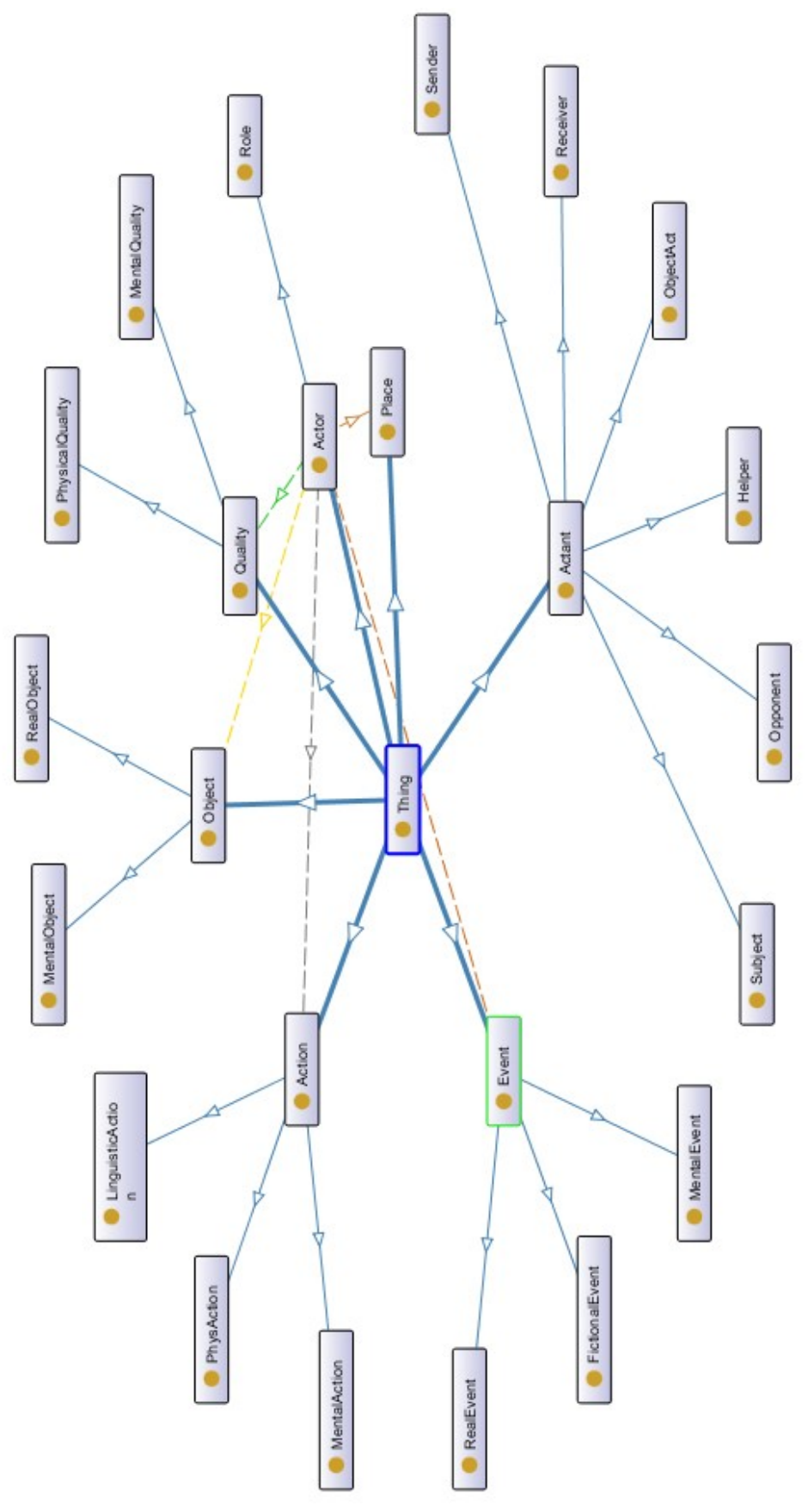

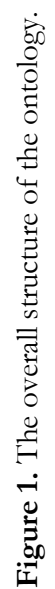


Another area of application of a narrative ontology is the semantic annotation of textual corpora. In this case the advantage is reciprocal: on the one hand, the annotation process can be guided and focused by way of the ontology, limiting the risks of divergent or irrelevant contributions, especially in a crowd-sourcing context. Furthermore, this semantic enrichment, based on dedicated reference ontology, allows the execution of complex queries and semantic analyses using automatic-reasoning tools.

On the other hand using an ontology to annotate texts requires finding the actual textual correlatives of the abstract and theoretical notions formalized in the ontology; this limits the risk of having purely speculative conceptual frameworks that do not cope with the reality of textual traditions. I believe that the availability of these kinds of formal models and frameworks can bring many relevant advances in the study of literary phenomena as well as in the didactics of literature.

\section{Conclusions and next steps}

The project I have theoretically described and the first draft of the ontology are of course only the provisional result of our research program, and I must say that there are still many open problems at the ontological modeling levels and at the technical implementation levels.

The first and foremost theoretical development is the definition of the fictional space ontology and of its relation with that of characters. There is a deep relation between the notion of character and that of narrative space. According to Lotman (1972) each character is defined by the narrative space to which it is bounded, and the hero is the only character that can move between different narrative spaces.

Although the work on this aspect of our ontology has yet to start, the concept of narrative space can be formalized using the notion of fictional possible worlds, whose definition is given by Eco:

a possible world is a possible state of affairs expressed by a set of relevant propositions where for every proposition either $p$ or $\sim$; as such it outlines a set of possible individuals along with their properties; since some of these properties or predicates are actions, a possible world is also a possible course of events;

since this course of events is not actual, it must depend on the propositional attitudes of somebody; in other words, possible worlds are worlds imagined, believed, wished, and so on. (1979: 219)

A further development I can envision is the definition of a set of primitive abstract action types revisiting the conceptual dependency theory proposed by Roger Shank (1975); this is a very complex and controversial issue, 
but I think that most of the critical points that were raised by Shank's proposal can be undermined if they are conceived primarily as taxonomical meta-categories and not as cognitive primitives.

A further step is the comparison with other relevant ontologies in the field and when possible the mapping with them for inter-operability. The first candidates are the ontology developed by Zöllner-Weber's (Noctua literaria ontology, http:/ / www.figurenontologie.de) which is very similar in scope and aims (the analysis of literary works), but not in the structure (although there are some areas of overlapping). Then we can take into consideration more "industrial-oriented" ontologies like Ontomedia (http://www.contextus.net/), or "high-level" ontologies for cultural artifacts like CIDOC-CRM (http://www.cidoc-crm.org). A further development in this area is the possibility to link our domain-specific ontology with one or more foundational ontologies, although the feasibility and the advantage of this connection is questionable.

It is particularly relevant to publish the ontology and the data sets as Linked Data to link them to already existing datasets with similar or partially overlapping information in the Cultural Heritage LOD cloud.

Finally, the applications of a formal ontology of narrative are not limited to literary studies. In these years, the attention towards storytelling has also increased in social sciences, media and game studies, enterprise communication. My modeling effort can find relevant intersections and applications inside these domains too. I believe in fact that a model of storytelling based on a rich description of fictional characters and worlds can be more effective than those limited to action theory and story grammars formalization.

\section{References}

ANTONIOU, Grigoris, Frank Van Harmelen (2008). A Semantic Web Primer. Cambridge, Mass.: MIT Press.

BAADER, Franz, Sebastian Brandt, and Carsten Lutz (2005). "Pushing the EL envelope." IJCAI. 5: 364-369.

BERNERS-LEE, Tim, James Hendler, and Ora Lassila (2001). "The Semantic Web." Scientific American 284.5: 34-43. doi:10.1038/scientificamerican0501-34.

CIOTTI, Fabio (2014). "Digital Literary and Cultural Studies: State of the Art and Perspectives." Between 4.8. doi: http://dx.doi.org/10.13125/2039$6597 / 1392$

DAMIANO, Rossana, Antonio Lieto (2013). "Ontological Representations of Narratives: a Case Study on Stories and Actions." Proceedings of CMN13 (Computational Models of Narratives). Hamburg. 76-83.

DENNETT, Daniel C. (1990). "The Interpretation of Texts, People and Other Artifacts." Philosophy and Phenomenological Research: 177-194. 
DOLEŽEL, Lubomír (1998). Heterocosmica: Fiction and Possible Worlds. Baltimore: Johns Hopkins University Press.

ECO, Umberto (1975). Trattato di semiotica generale. Milano: Bompiani.

(1979). The Role of the Reader. Explorations in the Semiotics of Texts. Bloomington: Indiana University Press.

GIGLIOZZI, Giuseppe (1986). "If (not, la nonna ha gli occhi grandi) Then... favole - computers e mondi possibili." Studi filosofici 7.9. Istituto Universitario Orientale, Dipartimento di filosofia e politica: 243-268.

(1987). "Codice, testo e interpretazione." Studi di codifica e trattamento automatico di testi. Ed. G. Gigliozzi. Roma: Bulzoni. 65-84.

(1991). "Il genere narrativo tra analisi e generazione. Principi teorici e applicazioni computazionali.” Rècit et informatique. Ed. C. Cazalé. La Garenne-Colombes: Éditions de l'Espace européen.

GIGLIOZZI, Giuseppe, and Sandra Giuliani (1993a). "Una parola che non dice nulla. Le «Novelle per un anno» di Luigi Pirandello. Due letture critiche e un esperimento d'analisi computazionale." Fine della storia e storie senza fine. Ed. C. Cazalé. Nanterre: Université Paris X - Nanterre. 87-89. (1993b). "La rete delle formiche. Un'applicazione di SebNet." Fine della storia e storie senza fine. Ed. C. Cazalé. Nanterre: Université Paris $\mathrm{X}$ - Nanterre.137-157.

GIGLIOZZI, Giuseppe, and Paolo Sensini (1987). "SEB - Sistema esperto per l'analisi di brani. Per un'analisi automatica di fiabe." Studi di codifica e trattamento automatico di testi. Ed. G. Gigliozzi. Roma: Bulzoni. 145-217.

GREIMAS, Algirdas Julien (1966). Sémantique structurale, recherche de méthode. Paris: Larousse.

(1983). Du Sens II - Essais sémiotique. Paris: Éditions du Seuil.

GRUBER, Thomas R. (1993). "A Translation Approach to Portable Ontology Specifications.” Knowledge Acquisition 5.2: 199-220. (2009). "Ontology." Encyclopedia of Database Systems. SpringerVerlag.

GUARINO, Nicola, Daniel Oberle, and Steffen Staab (2009). "What is an Ontology?" Handbook on Ontologies. Berlin Heidelberg: Springer. 1-17.

HEATH, Tom, Christian Bizer (2011). Linked Data: Evolving the Web into a Global Data Space. Synthesis Lectures on the Semantic Web: Theory and Technology. Seattle, WA: Morgan \& Claypool Publishers. doi:10.2200/S00334ED1V01Y201102WBE001

HERMAN, David (1999). Narratologies: New Perspectives on Narrative Analysis. Columbus: Ohio State University Press.

JEWELL, Michael O., et al. (2005). "OntoMedia: An ontology for the representation of heterogeneous media." Proceeding of SIGIR workshop on Multimedia Information Retrieval. ACM SIGIR.

JOCKERS, Matthew Lee (2013). Macroanalysis: Digital Methods and Literary History. Urbana: University of Illinois Press. 
LEHNERT, Wendy G. (1981). "Plot Units and Narrative Summarization." Cognitive Science 5.4: 293-331.

LOTMAN, Jury M. (1972). La struttura del testo poetico. Milano: Mursia.

MANI, Inderjeet (2013). Computational Modeling of Narrative. Synthesis Lectures on Human Language Technologies 18. Seattle, WA: Morgan \& Claypool Publishers.

MEISTER, Jan Christoph (2003). Computing Action. A Narratological Approach. Berlin: Walter De Gruyter.

MINSKY, Marvin Lee (1974). A Framework for Representing Knowledge. Cambridge: Massachusetts Institute of Technology A.I. Laboratory.

MORETTI, Franco (2013a). "Operationalizing: Or, the Function of Measurement in Literary Theory.” New Left Review 84: 103-119. (2013b). Distant Reading. London: Verso.

PROPP, Vladimir Jakovievĩc (1968). Morphology of the Folktale. Austin: University of Texas Press.

RYAN, Marie-Laure (1991). Possible Worlds, Artificial Intelligence, and Narrative Theory. Bloomington: Indiana University Press.

SCHANK, Roger C. (1975). Conceptual Information Processing. Amsterdam: North-Holland.

, Robert P. Abelson (1977). Scripts, Plans, Goals, and Understanding: An Inquiry Into Human Knowledge Structures. Hillsdale, N.J.: L. Erlbaum Associates.

UNDERWOOD, Ted (2012). "Topic Modeling Made Just Simple Enough." The Stone and the Shell. 7 Apr. 23 Jan. 2016.

https://tedunderwood.wordpress.com/2012/04/07/topic-modelingmade-just-simple-enough/

VAN DIJK, Teun A. (1977). "Perspective Paper: Complex Semantic Information Processing." Natural Language in Information Processing. Eds. D.E. Walker, H. Karlgren and M. Kay. Skriptor: Stockholm. 127-163.

(1979). "Cognitive Processing of Literary Discourse." Poetics Today: 143-159.

W3C. (2012a). "OWL 2 Web Ontology Language Document Overview." Second Edition. 23 Jan. 2016. http://www.w3.org/TR/owl2-overview (2012b). “OWL 2 Web Ontology Language Profiles." Second Edition. 23 Jan. 2016. http:/ /www.w3.org/TR/owl2-profiles/

(2013). "RIF Primer." Second Edition. 23 Jan. 2016. http://www.w3.org/TR/2013/NOTE-rif-primer-20130205/

ZÖLLNER-WEBER, Amélie (2006). "Formale Repräsentation und Beschreibung von literarischen Figuren." Jabrbuch für Computerphilologie 7. Ed. G. Braungart, P. Gendolla, and F. Jannidis.187-203. (2007). "Noctua literaria - A System for a Formal Description of Literary Characters." Data Structures for Linguistic Resources and Applications. Ed. G. Rehm, A. Witt, A., and L. Lemnitzer. Tübingen. 113-121. 
(2009). "Ontologies and Logic Reasoning as Tools in Humanities?” Digital Humanities Quarterly 3.4). 23 Jan. 2016.

http://www.digitalhumanities.org/dhq/vol/3/4/000068/000068.html ZÖLLNER-WEBER, Amélie, and Andres Witt (2006). "Ontology for a Formal Description of Literary Characters." Proceedings of Digital Humanities 2006. Paris. 350-352.

(C) 2016 Fabio Ciotti.

Licensed under the Creative Commons Attribution-NoncommercialNo Derivative Works 4.0 International (CC BY-NC-ND 4.0). 